\title{
THE INTERPRETATION(S) OF PREDICATION
}

\section{Uwe Meixner}

\begin{abstract}
In the course of the history of Western philosophy, various philosophers have given various answers to the question of the ontological basis of predication. This essay presents the main, the crucial answers: the paradigms and theories of predication of the Sophists (and of all later radical relativists), of Plato, of Aristotle, of the Aristotelian-minded non-nominalists, of Leibniz, and of Frege. The essay follows (to some extent) the most influential - the Aristotelian or quasi-mereological - paradigm of predication in its continuity and modification through the many centuries of its reign. But this essay is not content to adopt the merely historical point of view; it also poses the question of adequacy. Prior to Frege, a philosophically satisfactory theory of predication was not even in the offing, and the essay points out the shortcomings (besides aspects that can be viewed as advantages) of each pre-Fregean predication-theory it considers. Frege, in the $19^{\text {th }}$ century, brought the philosophy of predication on the right track. But his own theory of predication has its own deficits (which it shares with still other predication-theories). The essay ends with the presentation of a theory of predication that the author himself considers adequate.
\end{abstract}

In the economy of science, and of knowledge in general, simple predicative statements have a fundamental and indispensable role to play. Such statements, simple as they are: containing no logical functors, have various forms in natural language. Here is a far-from-complete list of such forms, each item in the list combined with an illustrative example:

\begin{tabular}{ll}
\hline FORMS & EXAMPLES \\
\hline$\alpha \Phi s[$ covering also: $\alpha$ is] & Kate laughs \\
\hline$\alpha$ is $\Phi$ & Kate is beautiful \\
\hline$\alpha$ is $\alpha \Phi$ & Kate is an actress \\
\hline$\alpha \Psi s \beta[$ covering also: $\alpha$ is $\beta]$ & Kate loves George \\
\hline$\alpha$ is $+p r \beta$ & Kate is in Boston \\
\hline$\alpha$ is $\Phi+p r \beta$ & Kate is married to George \\
\hline$\alpha$ is $a \Phi+p r \beta$ & William is a descendant of Albert \\
\hline$\alpha$ is $+p r \beta$ and $\gamma$ & The tree is between the house and the street \\
\hline$[p r:$ some preposition] &
\end{tabular}


Notwithstanding these many forms, the general form of simple predicative statements, which is familiar from first-order predicate logic, is just this:

$$
\Phi\left(\alpha^{1}, \ldots, \alpha_{N}\right)
$$

Here the sequence " $\alpha 1, \ldots, \alpha_{N}$ " represents the occurrences of the singular terms in a simple predicative statement, all of them without syntactical structure, in the order in which they follow each other in the statement (noting that a singular term may occur more than once in it); and the letter " $\Phi$ " represents the rest of the statement: the predicative basis, devoid of all logical functors, in which all of the occurrences of singular terms in the statement are embedded; finally, the unifying function of the predicative basis is indicated by the embracing brackets, "(" and ")". In order to make matters as simple as possible - that is: in order to focus on the basic problem of predication - I stipulate, in addition to the description of simple predicative statements just given, that the singular terms in simple predicative statements are not to refer to linguistic items or abstract entities, and that the predicates in simple predicative statements are to be chosen accordingly.

Some simple predicative statements are true. But from the earliest times of philosophy to this day the nature of the truth of true simple predicative statements has been controversial among the philosophers. Does the truth of such statements have ontological import? And if it has ontological import, what exactly is that import? These questions are philosophical evergreens, and not accidentally so: their importance can hardly be overestimated. For what is at stake in these questions is nothing less than the basic determination on what it truly amounts to when we claim to have knowledge of the world and to speak the truth about the world. In this essay, I shall look at some of the milestones of a discussion that spans almost 25 centuries: among other predication-theories, at the theories of Plato, Aristotle, and the Aristotelian-minded non-nominalists, at the theories of Leibniz and of Frege. At the end of the essay, I shall briefly present my own approach.

The positions on predication of the just-mentioned philosophers - different as they are - have at least one thing in common: all of them are opposed to the view that simple predicative statements have no ontological import at all. According to the no-ontological-import view, if a simple predicative statement is true, then its truth is a product merely of social convention, and hence a product merely of the allocation of power in the relevant group of speakers, since social convention follows social power. This view - the conviction that social convention, social power are the basic truthmakers, that basic truth itself is a social construction - was present at the beginning of philosophy in the teachings of the Sophists, it unmistakably shines through the voluntarism of mediaeval nominalists, and it reappears recognizably in the philosophy of the later Wittgenstein. ${ }^{1}$

${ }^{1}$ Significantly, Wittgenstein says the following in the Philosophical Investigations (§ 381): "How do I know that this colour is red? - It would be an answer to say: 'I have learnt English." 
Put formally, that is: in the most general way, the described view is this:

Social conventionalism in predication-theory:

" $\Phi\left(\alpha^{1}, \ldots, \alpha_{N}\right)$ " is true - this amounts, "ontologically", to the following: $\left\langle\alpha^{1}, \ldots, \alpha_{N}\right\rangle$ is purely on the basis of social convention designated by the general term " $\Phi$ ".

Hence, for the special case of non-relational predications:

" $\Phi(\alpha)$ " is true - this amounts, "ontologically", to the following: $\alpha$ is purely on the basis of social convention designated by the general term " $\Phi$ ".

If this were true, then the following instantiation of this general schema would have to be true, too:

"Kate is a woman" is true - this amounts, "ontologically", to the following: Kate is purely on the basis of social convention designated by the general term "woman".

Now, this does not seem to be true; for, while it is true that Kate is a woman, it is hard to believe that Kate is purely on the basis of social convention designated by the general term "woman".

On the other hand, I can to some extent understand it - psychologically - if social conventionalism in predication-theory is adopted as a weapon against classifications that are, one feels, merely socio-conventionally based but masquerade as hard and objective, ontologically based truths. One may be prompted by the - hardly rational - implicit belief that the charge "Mere convention!", if advanced against such classifications, can only be truly effective in one's mouth if one has managed to convince oneself of its being true for all classifications that are generally thought to be true.

A fundamental attitude of protest against established social power-mere power, but manifesting itself, the protester believes, in disguise: in simple predicative statements that rather persuasively pretend to express incontrovertible objective facts - may be something that modern feminist philosophers ${ }^{2}$ have in common with the ancient Sophists. The prime target of the Sophists, however, were not simple predicative statements expressing what is generally regarded to be natural facts, but simple predicative statements expressing what is generally regarded to be axiological facts, statements like "This decision is just", or "That deed is courageous", where everyone in the community, on being informed of the relevant circumstances, feels compelled to say, "Yes, that's true". Nevertheless, it is total, unrestricted social conventionalism in predication-theory which, very plausibly, underlies the famous homo-mensura-dictum of the Sophist Protagoras, according to which "man is the measure of all things, of the things that are, that they are, and of the things that are not, that they are not". Applying the homo-mensuradictum to axiological statements, one can very well declare that "This decision is just" and "This deed is courageous" are true (in the relevant circumstances) - "as

${ }^{2}$ For example (and paradigmatically), Judith Butler. 
everybody says they are"; but one will add that all that is implied by these truths is this: the mentioned decision is purely on the basis of social convention designated by the term "just", and the mentioned deed is purely on the basis of social convention designated by the term "courageous"; for man - in another word: society, in other words: the social group which is in power - is the measure of all things.

It was this utterly subversive attitude that Plato, following Socrates, was reacting against. His philosophically most significant move in this was to offer a predication-theory which is not conventionalistic. Showing full awareness of the problem of predication, Plato came up with the first explicitly formulated predication-theory ever. Now, Plato, in the course of his career as a philosopher, underwent substantial development in his thinking about predication, and in fact, in later phases, became critical of earlier positions of his. But this did not hinder that the predication-theory that is imposingly present in the dialogues from the middle of Plato's career - in the Symposium, the Phaedo, the Republic - had a massive effect on the history of ideas. Very soberly - quite without the poetic splendour of philosophical mythology - that predication-theory can be formulated in the following way (and Plato himself formulates it that way in Parm., $132 \mathrm{~d} 1-5$ ):

Plato's (classical) predication-theory:

" $\Phi(\alpha)$ " is true - this amounts, ontologically, to this: $\alpha$ is sufficiently similar to the $\Phi$ itself.

Applying this theory, we get for example:

"This deed is just" is true - this amounts, ontologically, to the following: this deed is sufficiently similar to the just itself.

"Kate is beautiful" is true - this amounts, ontologically, to the following: Kate is sufficiently similar to the beautiful itself.

"Kate is a woman" is true - this amounts, ontologically, to the following: Kate is sufficiently similar to the woman itself.

Even when divested of its poetic splendour (involving an eternal, unchangeable transcendent realm of being itself, which one is likely to imagine awash with "the white light of truth"), Plato's predication-theory has fascinating features. One of them is, of course, the introduction of an entirely new order of objects: the eide, as Plato called them, the separate forms, serving as paradeigmata: the just itself, the beautiful itself, the woman itself, and so on. And note, since the $\Phi$ itself is certainly sufficiently similar to the $\Phi$ itself (no matter which general term $\Phi$ we are looking at), Plato's predication-theory has the following logical consequence:

Platonic self-predication:

$\Phi$ (the $\Phi$ itself). 
Thus, the beautiful itself is beautiful, the just itself is just, the human being itself is a human being. Indeed, since the $\Phi$ itself is not only sufficiently similar to the $\Phi$ itself, but is the only object that is maximally similar to it, in other words: the only object that is identical to it, the logic of Plato's predication-theory requires that the $\Phi$ itself is the unique object that is maximally $\Phi$. Thus, the beautiful itself is the unique object that is maximally beautiful, the just itself is the unique object that is maximally just - and all the other beautiful or just items are beautiful or just only by being more or less remote likenesses of those two eide. - And, note, according to Plato's predication-theory, the woman itself is the unique object that is maximally a woman.

Unfortunately, this last consequence, if nothing else, constitutes a reductio ad absurdum of Plato's predication-theory. If there is such a thing as the woman itself, it is certainly not maximally a woman, nor even a woman. Plato himself noted (through the mouth of one of his dramatis personae: Parmenides) that it seems ridiculous to postulate that there are such things as the hair itself, or the dirt itself (cf. Parm., 130 c 7-8). Even if the existence of such eide were not ridiculous, it would still be incontrovertibly absurd to suppose, as Plato's predication-theory forces one to suppose, that no other dirt is dirt in the degree that the dirt itself is dirt.

This is a much more serious problem for Plato's predication-theory than the much canvassed so-called Third-Man-Argument, which, in essence, can already be found in Plato's dialogue Parmenides and might also be called "the Third-LargeObject-Argument" (see Parm. 132 a 1-b 2). It can be put in the following way:

The visible large objects are large in virtue of participating in a first largeness. But this first largeness is another large object. Hence the first-mentioned large objects and this other large object are large in virtue of participating in a second largeness. But, again, this second largeness is another large object. Hence the first-mentioned large objects, the second-mentioned one and this now apparent third large object are large because they participate in a third largeness. But, again, this third largeness is another large object - and so on ad infinitum.

This argument tries to settle Plato's predication-theory - not only for the term "large", which is merely an example, but for each and every general term that can be truthfully applied in the empirical world - with an infinite number of different eide without a real difference to them. But the argument fails. According to Plato's predication-theory, the visible large objects and the first largeness are indeed large, but not in virtue of participating in a second largeness: the visible (or empirical) large objects are large because they are sufficiently similar to the first largeness, and the first largeness is large - for the same reason: it is sufficiently similar to (since it is identical with) the first largeness: the large itself. Thus, there is no need whatsoever to postulate any other largeness than the first largeness. 
Plato's predication-theory has, however, a very limited scope of plausible applicability. There are some cases where the theory is not obviously inadequate: statements like "Kate is beautiful" and "Kate is just". But the theory is certainly not adequate for the statement "Kate is a woman", or even the statement "Kate is a human being" - or, for that matter, for the statements "Kate is hungry" and "Kate is pregnant", although these latter two statements have adjectives standing in predicative position just as the statements "Kate is beautiful" and "Kate is just" have. Moreover, Plato's predication-theory is meant for non-relational predications only - and, in fact, I have formulated it only for non-relational predications. If one tries to extend it to relational predications, inadequacy looms large: Suppose the statement "George loves Kate" is true; but does this mean - in the spirit of Plato - that the ordered pair consisting of George in the first place, and of Kate in the second, is sufficiently similar to love itself? Presumably not. However, the mystical implications of this Platonising ontological interpretation of the statement "George loves Kate" will surely not fail to fascinate minds that are receptive to such implications. The same can be said of the mystical implications of the Platonic ontological readings of simple predicative statements that are straightforwardly true and involve the term "good" as predicate, or merely the word "is". Given acceptance of the classical Platonic predication-theory, it is possible to elevate oneself - as it were - in one leap from rather earthly matters right up to the transcendent Godhead Itself (though only in ontological theory). Especially in Late Antiquity and the Early Middle Ages there were many minds that very much appreciated this asset of the Platonic predication-theory.

Inadequate treatment of relational predications is a deficiency that is shared by all predication-theories prior to Frege's. It is a deficiency not only Plato can be criticised for. Nor is the long persistence of it due to Plato's influence. As a matter of fact, its persistence is due to the influence of Aristotle.

In Plato's predication-theory, the partners of predication - the ontological subject and the ontological predicate - are external to each other, just as a likeness is external to what it is a likeness of. Moreover, in Plato's predication-theory, the ontological predicate is the dominant partner in predication. Aristotle, however, adheres to a paradigm of predication that is fundamentally different from Plato's, a paradigm that is also rather more down to earth than Plato's. According to Aristotle's paradigm, the ontological subject is the dominant partner in predication, and the ontological predicate is, in predication, in some sense encompassed by the ontological subject, comparable to the way in which a part is encompassed by what it is a part of. There are significant indications that Plato himself was moving towards some form of the mereological or, better, quasi-mereological paradigm of predication in the latter part of his philosophical career. ${ }^{3} \mathrm{But}$, in

${ }^{3}$ See FRAnZ VON KutSCHERA,"Parts of Forms. An Essay concerning Plato's Parmenides". Logical Analysis and History of Philosophy 1 (1998): 57-74. 
the main, the origin of this paradigm must be associated with Aristotle. Mainly on the basis of the wide-spread reception of Aristotle's writings since the beginning of the $13^{\text {th }}$ century, the quasi-mereological paradigm of predication became rather influential in Western philosophy. It stayed the standard approach for just about six centuries. Aristotle's predication-theory - which means: the predicationtheory which, given the data from Aristotle's writings, is the best summative reconstruction of his opinions on predication - is a particular version of the quasi-mereological paradigm (which, indeed, has many versions); it can be put in the following way:

Aristotle's predication-theory /

The quasi-mereological predication-theory with particular forms:

" $\Phi(\alpha)$ " is true - this amounts, ontologically, to the following: the $\alpha$-particular form of being $\Phi$ is in $\alpha$.

Thus we have for example:

"Socrates is wise" is true - this amounts, ontologically, to the following: the Socrates-particular form of being wise is in Socrates.

"Kate is beautiful" is true - this amounts, ontologically, to the following: the Kate-particular form of being beautiful is in Kate.

"Kate is a woman" is true - this amounts, ontologically, to the following: the Kate-particular form of being a woman is in Kate.

It should be noted that a special case of the situation that the $\alpha$-particular form of being $\Phi$ is in $\alpha$ is this: the $\alpha$-particular form of being $\Phi$ is identical to $\alpha$; this is the traditional Aristotelian ontological analysis of, so-called, substantial predication (as in "George is a man"); whereas if the $\alpha$-particular form of being $\Phi$ is in $\alpha$, but is not identical to $\alpha$, we have before us the traditional Aristotelian ontological analysis of, so-called, non-substantial predication (as in "George is sitting").

There are two plausible equivalents for the phrase "the $\alpha$-particular form of being $\Phi$ is in $\alpha$ ", each of which, if substituted for that phrase in Aristotle's predication-theory, yields a predication-theory that is plausibly equivalent to Aristotle's predication-theory:

(1) Plausibly, "the $\alpha$-particular form of being $\Phi$ exists" is true if, and only if, the $\alpha$-particular form of being $\Phi$ is in $\alpha$.

(2) Plausibly, "the form of being $\Phi$ is in $\alpha$ " is true if, and only if, the $\alpha$-particular form of being $\Phi$ is in $\alpha$.

But in fact Aristotle denies that

The quasi-mereological predication-theory with universal forms:

" $\Phi(\alpha)$ " is true - this amounts, ontologically, to the following: the form of being $\Phi$ is in $\alpha$, 
is true. In the Categories (Cat. 1 a 20-23; see also Cat. 3 a 11-13), he declares that Man - in other words: the form of being a human being - is, on the one hand, (truthfully) said of a subject, namely, of a particular human being, but that it is, on the other hand, not in any subject. This can only be taken to imply that, according to Aristotle, the statement "George is a human being" is true, although the form of being a human being is not in George, and that therefore the quasimereological predication-theory with universal forms is not true (because it is counter-instantiated).

Indeed, the quasi-mereological predication-theory with universal forms can seem to be rather non-equivalent to the quasi-mereological predication-theory with particular forms, that is: to Aristotle's predication-theory. After all, the former theory involves universal forms, the latter only particular ones. But scepticism regarding universal forms - or briefly, universals - was certainly not Aristotle's problem with the former theory: he accepted universal forms at least as secondary entities, whereas he did not accept Plato's eide, that is, Plato's separate forms. ${ }^{4}$ His problem was that some universal forms are said of some subjects, but are not in any subject because they can exist apart from any subject they may tentatively be supposed to be $\mathrm{in}^{5}$ - because, as Aristotle believed at one point, they are substances: universal - or second - substances (in contrast to particular - or first - substances). ${ }^{6}$ However, in several places of the Metaphysics, we also find Aristotle denying that universals - any universals - are substances. ${ }^{7}$ Now, if no universal were a substance for Aristotle after all, then it would seem most plausible to assume that, for Aristotle, any universal is said (truthfully) of a subject ${ }^{8}$ after all on the

${ }^{4}$ For an explicit statement of Aristotle's acceptance of universals in contrast to Plato's separate forms, see An. Post. 77 a 5-9; that passage also contains Aristotle's definition of universal, which is this: one which can be truthfully said of many.

${ }^{5}$ See Cat. 1 a 24-25, where Aristotle defines - or rather: gives a partial explication of - being in a subject: "In a subject I call that which exists in something, but not as a [literal] part, and cannot be separate from that in which it is." [Translation U. M.] Note that the "cannot be separate from" is not meant by Aristotle to express a symmetrical relationship: " $x$ cannot be separate from $y$ " does not entail, for Aristotle, " $y$ cannot be separate from $x$ ". For he understands " $x$ cannot be separate from $y$ " in the sense of " $x$ cannot exist apart from $y$ ", and " $y$ cannot be separate from $x$ " in the sense of " $y$ cannot exist apart from $x$ ", and of course it can be - and sometimes is - the case that $x$ cannot exist apart from $y$, while $y$ can very well exist apart from $x$.

${ }^{6}$ That this is the correct diagnosis is strongly suggested by Cat. 3 a 7-15. Regarding Aristotle's asserting separability - the ability to exist apart from any supposed subject - of substances, see Met. VII, 1029 a 27-28. But note that in the same short passage Aristotle also asserts particularity of substances.

${ }^{7}$ See Met. III, 1003 a 8-10; Met. VII, 1038 b 8-12, 34-37, 1041 a 3; Met. X 1053 b 16-20; Met. XIII 1087 a 2.

${ }^{8}$ Note that for Aristotle any universal is said truthfully of some subject (because it is by definition truthfully said of many subjects; cf. note 4). 
necessary and sufficient basis of its being in that subject (though in it only in a derivative, analogical sense) - Man and Animal being no exceptions to this rule.

In any case, vacillations in Aristotle's writings are bound to have contributed, in the centuries after Aristotle and especially in the Middle Ages, to the waning of his distinction between universals that are not substances and are in some subject, and universals that are substances and are not in any subject. This distinction - a significant residue of Platonism in Aristotle - became less and less important. The distinction finally dissolved - in favour of all universals being just as much in some subject as all universals are said of some subject, and in favour of all universals being precisely in the subjects of which they are said. A striking documentation of the endpoint of this development can be found in the commentary of Thomas Aquinas on the Posterior Analytics of Aristotle. There, Thomas simply connects a universal's being (truthfully) predicated of a subject, being said of a subject, with its being in the subject of which it is predicated; no distinction is made in his characterisation of predication between substantial and non-substantial universals. Interpreting Aristotle, Thomas says (In Posteriorum Analyticorum I, lect. 11, n. 6):

Primo, dicit [Philosophus: Aristotle] quod tunc est universale praedicatum, cum [cum iterativum] non solum in quolibet est de quo praedicatur, sed et primo demonstratur inesse ei, de quo praedicatur.

Firstly, he [the Philosopher] says that a universal is a predicate [of something: $\alpha$ ] whenever it is not only in everything of which it is predicated, but is first demonstrated to be in that [i.e., the something: $\alpha$ ] of which it is predicated.

From this quotation, it is apparent that Thomas accepted - under the presumed authority of Aristotle - the quasi-mereological predication-theory with universal forms, because the quotation can, without much effort, be made to support the following reasoning that yields just that predication-theory:

1. The (universal) form of being $\Phi$ is (demonstrated to be) in $\alpha$.

2. Hence according to Thomas ["tunc est universale praedicatum, cum ... demonstratur inesse ei, de quo praedicatur"]: the form of being $\Phi$ is (truthfully) predicated (said) of $\alpha$.

3. And hence: " $\Phi(\alpha)$ " is true.

1'. “ $\Phi(\alpha)$ " is true.

2'. Hence: the form of being $\Phi$ is (truthfully) predicated (said) of $\alpha$.

3'. Hence according to Thomas ["universale... in quolibet est de quo praedicatur"]: the form of being $\Phi$ is in $\alpha$.

Now, as long as one assumes what Aristotle himself at some time - for some cases - did not assume, namely, 
that "the form of being $\Phi$ is in $\alpha$ " is true if, and only if, the $\alpha$-particular form of being $\Phi$ is in $\alpha$ [cf. the plausible assumption (2) above],

the quasi-mereological predication-theory with universal forms will be found to be equivalent to the quasi-mereological predication-theory with particular forms. This equivalence and, in the first place, the assumption on which it is based seem plausible without argument. One can also rather plausibly argue for them in the following way:

Asserting of a universal form that it is in a subject is merely a non-literal, analogical way of speaking. Such an assertion cannot be literally true, because the universal form is not a particular, whereas the subject is one. Only a particular can be literally in a particular. What is literally true in those cases where a universal form is truthfully but analogically said to be in a subject can only be this: the particularisation relative to the subject of the universal form is literally - in the subject.

Thomas and his Aristotelian-minded non-nominalist contemporaries and successors - and, for that matter, Husserl, who much later in the history of ideas once again followed Aristotelian lines in formal ontology - would have found this argument entirely convincing. ${ }^{9}$ However, the history of ideas after the Middle Ages took a course that was not in keeping with the argument's Aristotelian spirit. After the Middle Ages one rather tended to forget the analogical equivalence - Aristotelian in spirit - of the quasi-mereological predication-theory with universal forms to the quasi-mereological predication-theory with particular forms, an equivalence based on the assumption that the phrase "the form of being $\Phi$ is in $\alpha$ " is merely an analogical façon de parler (though no denial of universal forms is involved in that assumption) and that the phrase's ultimate truth-relevant import - what it really says - just amounts to what is expressed by the phrase "the $\alpha$-particular form of

${ }^{9}$ Regarding Husserl, the following passage from his lecture Phenomenological Psychology [Phänomenologische Psychologie] of 1925 rather strongly suggests his being ready to uphold the two classical quasi-mereological predication-theories simultaneously, the universalistic one standing, as it were, on top of the particularistic one: "One must not believe that the identity of the eidos [which for Husserl merely amounts to the universal] isjust an exaggerating way of speaking. ... [It is not merely the case that] every object has its in-being moment, for example, of redness, and [that] each of the many objects, all of which are red, has its individually own moment, but in sameness. Rather, one must see that the sameness is only a correlate of the identity of something that is general and in common [eines Allgemeinen], that can, in truth, be intuited as one and the same out of - and as a 'counterpart' of - what is individual. This identical something 'particularises' itself in many ways and can be thought, in an open infinity, arbitrarily particularised. All of these particularisations are, in virtue of their relationship to what is identical, related to each other, and are accordingly called 'each the same as the other'. In an extended, non-literal way of speaking, the concrete objects themselves are, in virtue of having eidetic particularisations in them, each called the same as the other 'with respect to the red', and are themselves, in a non-literal sense, particularisations of the something that is general and in common [des Allgemeinen]." - Phän. Psych., 80; translation and italics U. M. 
being $\Phi$ is in $\alpha$ ", or by the equivalent phrase "a particularisation of the form of being $\Phi$ is in $\alpha$ " - these phrases being taken to express the original Aristotelian ontological basis for predication..$^{10}$ After the Middle Ages, the quasi-mereological predication theory with universal forms started a life of its own.

During the Renaissance, due to the influx of ancient Platonic texts to Italy after the fall of Constantinople in 1453, there was a significant resurgence of Platonism, broadly conceived. This led to a very strong reaction against the Aristotelianism of the Schools and - combining with forces that emphasised the importance of the individual human being, of the individual human mind - brought about the philosophical (so-called) Enlightenment of the $17^{\text {th }}$ century. In the field of ontology, a significant consequence of these revolutions was the following: universals turned into absolute concepts for those thinkers who, on the one hand, did not deny universals, like the nominalists had always done, and who on the other hand, Platonically and humanistically inspired, did not want to continue along the old mediaeval Aristotelian lines. For those thinkers, universals took on an absoluteness that traditional Aristotelians had not conceded to universals; it faded into the background that universals were supposed to be anthropogenic abstractions from particulars. At the same time, those thinkers emphasised the conceptualness of universals more strongly than it had ever been: the affinity of universals to mind - which, given the absoluteness newly accorded to universals, could of course only be their affinity to a transcendent supermind. Mind-affinity had to some extent already been a characteristic of Plato's eidē. But it was Plotinus who had, in late Antiquity, explicitly conceptualised the eide by

10 See R. E. Allen, "Substance and Predication in Aristotle's Categories", in Exegesis and Argument. Studies in Greek Philosophy Presented to Gregory Vlastos, ed. E. N. Lee et al. (Assen, Netherlands: van Gorcum, 1973), 367: "If Socrates is just, there is, according to the Categories, an instance of justice in him, an instance which is individual, numerically one, and inseparable from Socrates in the sense that it cannot exist apart from him." In other words: If Socrates is just, there is a particularisation of the form of being just ("an individual instance of justice") in him - and, clearly, that particularisation is the Socrates-particular form of being just. In general we have: (a) If a particularisation of the form of being $\Phi$ is in $\alpha$, then the $\alpha$-particular form of being $\Phi$ is in $\alpha$ (because every particularisation of the form of being $\Phi$ that is in $\alpha$ is identical with the $\alpha$-particular form of being $\Phi)$. And we also have the converse: (b) If the $\alpha$-particular form of being $\Phi$ is in $\alpha$, then a particularisation of the form of being $\Phi$ is in $\alpha$ (because the $\alpha$-particular form of being $\Phi$ is, if in $\alpha$, a particularisation of the form of being $\Phi)$. One can derive both (a) and (b) on the basis of the following definition: the $\alpha$-particular form of being $\Phi=_{\text {Def }}$ the particularisation of the form of being $\Phi$ that is in $\alpha$-presupposing, for all cases of $\alpha$ and $\Phi$, that there is no more than one particularisation of the form of being $\Phi$ that is in $\alpha$ and that there is a particularisation of the form of being $\Phi$ that is in $\alpha$ if the particularisation of the form of being $\Phi$ that is in $\alpha$ is in $\alpha$. One might object that there can easily be more than one particularisation of the form of being red (for example) in a subject: if a table has a red area here and a red area there. But one can stipulate that the phrase "[there is] a particularisation of the form of being $\Phi$ [that] is in $\alpha$ " is understood to refer, if true, to the (relatively to $\alpha$ ) entire particularisation of the form of being $\Phi$ in $\alpha$. 
making them denizens of the nous, while maintaining their absoluteness, their ontological independence from particulars. It is not unlikely that the influence of Plotinus (via Marsilio Ficino and Pico della Mirandola) helped bring about the described post-mediaeval developments. ${ }^{11}$

Remarkably, these developments did not necessarily endanger the acceptance of the quasi-mereological paradigm, that is, of precisely that paradigm of predication that Aristotle, setting himself off from Plato, had inaugurated with his particular version of a quasi-mereological predication-theory. The predicationtheory of Leibniz can serve as a striking example of a syncretistic result of the post-mediaeval developments I just sketched. Leibniz was an Enlightened follower of the quasi-mereological paradigm and, in fact, had more sympathies with traditional Aristotelianism than most of the new intellectuals of his time. He did subscribe to the Scholastic slogan of praedicatum inest subjecto, but he did so in a new manner, reflecting the revolution of ideas which had come about. In Section 8 of the Discours de Métaphysique he very clearly formulates

Leibniz's predication-theory:

" $\Phi(\alpha)$ " is true - this amounts, ontologically, to the following: the $\Phi$-concept is in the $\alpha$-concept.

Obviously, the predication-making relation of in-being (inesse) in Leibniz's predication-theory is neither of the two relations of in-being that are invoked in the two previously canvassed quasi-mereological predication-theories. In fact, it is not a relation of in-being between the predicate and the subject at all: it is a relation between the predicate-concept and the subject-concept. This latter relation of inbeing, between concepts, was already at the time of Leibniz not a newly discovered one; it had already been familiar for a long time, and, as a matter of fact, it had not been clearly distinguished from the other two relations of in-being I have already considered..$^{12}$ The common form of the statements "homo est animal" and "Socrates est homo" suggests that they both are simple predicative statements, and that therefore the relation of in-being invoked under a quasi-mereological theory of predication for analysing "Socrates est homo" must be the same as the relation of in-being invoked for analysing "homo est animal". But in fact "homo est animal" is not a simple predicative statement - it is a statement of essential subsumption. It is true that "homo est animal" is true in virtue of the animalconcept being in the homo-concept (or in other words: in virtue of the extension

${ }^{11}$ From the $17^{\text {th }}$ to the $19^{\text {th }}$ century, the idea of the mind-affinity, the conceptualness of universals remained present, but, progressively, it took on decidedly human proportions; for the initially co-present Platonic/Plotinic idea of the absoluteness of universals progressively disappeared - until it triumphantly re-appeared in the work of Frege.

${ }^{12}$ For the history of in-being between concepts and its relationship to predicative in-being, see UWE MEIXNER, "Negative Theology, Coincidentia Oppositorum, and Boolean Algebra", Logical Analysis and History of Philosophy 1 (1998): 75-89. 
of the homo-concept being essentially subsumed under the extension of the animalconcept). But it does not follow from this that the simple predicative statement "Socrates est homo" is, analogously, true in virtue of the homo-concept being in the Socrates-concept - because "homo est animal" cannot serve as a paradigm for "Socrates est homo", since "homo est animal" is, contrary to appearances, not a simple predicative statement, but a statement that is different in meaning from "Socrates est homo" even in the very category of meaning.

Thus, Leibniz's predication-theory would seem to rest on a simple confusion: the confusion of the in-being of a universal in a particular with the in-being of one concept in another - if one weren't reluctant to settle the great man with such a big blunder. And, indeed, there is a more favourable perspective on Leibniz's predication-theory than that: Given that the quasi-mereological predication-theory with universal forms emancipated itself in post-mediaeval times along the lines I have described (which emphasise both the absoluteness and the conceptualness of universals) from the quasi-mereological predication-theory with particular forms, the problem of how a universal predicate could be in a particular subject needed a new solution. In this situation, making use of the relation of inbeing between concepts must have seemed the only way to go. It was, therefore, not unreasonable - relatively speaking - of Leibniz to interpret "praedicatum inest subjecto" as "the predicate-concept is in the subject-concept". What else could it mean?

Leibniz dauntlessly accepted the strange consequences of his predicationtheory: that Alexander once defeats Darius (cf. Discours de Métaphysique 8) - this is so because the concept of once defeating Darius is in the concept of Alexander; that Caesar once crosses the Rubicon - this is so because the concept of once crossing the Rubicon is in the concept of Caesar (cf. Discours de Métaphysique 13). But if this is true, then these historical truths about Caesar and Alexander, which we regard as contingent, are not contingent at all, but necessary truths in the strictest sense. We human beings learn only a posteriori and never completely - and hence with an almost irresistible appearance of contingency - what is, for example, the content of the concept of Caesar (a consistent concept maximally rich in content, a notio completa). But, according to Leibniz, that concept cannot be otherwise for Caesar than it is (would it be otherwise, then it wouldn't be the concept of Caesar), and God, according to Leibniz, knows it a priori and completely. Because Caesar once crosses the Rubicon, the concept of once crossing the Rubicon is contained in that concept of Caesar according to Leibniz's predication-theory - we just saw -, hence contained in it with strict necessity, since the relation of in-being between concepts is a relation that holds with strict necessity whenever it holds at all. ${ }^{13}$ And hence it follows, again according to Leibniz's predication-theory, that

${ }^{13}$ For concluding that the concept of once crossing the Rubicon is necessarily contained in the concept of Caesar, the reason given is, in fact, not in itself sufficient: "the concept 
it is necessary in the strictest sense that Caesar once crosses the Rubicon. Leibniz might have noticed that we can learn to know the concept of Caesar a posteriori (which is the only way for us) only by coming to believe in the truth of simple predicative statements about Caesar - and that for our coming to believe in the truth of these statements the concept of Caesar is, in fact, entirely irrelevant. This might have given pause to Leibniz.

Like all predication-theories prior to Frege's, Leibniz's predication-theory is not adequate for relational predications, although, because it deals in concepts, it is not as inadequate as other theories under the quasi-mereological paradigm. Notice that relational predications are implicit in the very examples Leibniz chooses: Alexander once defeating Darius, Caesar once crossing the Rubicon. It is possible to assimilate relational predications to non-relational ones, along the lines of "Caesar once crosses the Rubicon" being read as "Caesar is a Rubicon-crosser". And while it is surely absurd that an original-Aristotelian universal form of being a Rubicon-crosser is in Caesar - because it is absurd that an original-Aristotelian Caesar-particular form of being a Rubicon-crosser is in Caesar (Caesar carrying that thing around with him, and with it the Rubicon, it would seem) -, it is not absurd that the concept of being a Rubicon-crosser is in the concept of Caesar. But we have seen that, still, there are reasons for not accepting this as the basis that is appropriate for predicating being a Rubicon-crosser of Caesar.

A time came - by and large with the $19^{\text {th }}$ century - when the anti-relationalist, substantialist conception of the world began to loosen its grip on the human mind, and concatenations of non-privileged, non-dominant beings (such concatenations may be called "states of affairs") instead of privileged, dominant gravitational centres of being (such centres may be called "substances") began to capture the ontological imagination. But it took a philosopher-mathematician who had less respect - and probably less knowledge - of the philosophical tradition than Leibniz for progress to be made with regard to relational predications. Frege finally abandoned the quasi-mereological paradigm, and came up with something entirely new. There is no precedent or analogue in the antecedent history of ideas for

Frege's predication-theory:

" $\Phi\left(\alpha^{1}, \ldots, \alpha_{N}\right)$ " is true - this amounts, ontologically, to the following: the functional value of the $\Phi$-concept for $\left\langle\alpha^{1}, \ldots, \alpha_{N}\right\rangle$ is the true.

of Caesar" and "the concept of once crossing the Rubicon" must also each refer to one and the same (respective) concept in every possible world (compare the situation regarding the necessity or contingency of true identity statements). Leibniz certainly assumed the rigidity of the mentioned designators; but in the case of "the concept of Caesar" rigidity is, as a matter of fact, doubtful (the reason being this: if the concept of Caesar is the sum of all concepts that apply to Caesar, then that sum seems to be different in different possible worlds, since, apparently, in different possible worlds different concepts apply to Caesar). 
The intuitive oddness of this predication-theory decreases considerably if one takes into account that Frege conceived, in extension of the mathematical concept of a function, of concepts as functions whose functional values are the true or the false, and of functions, employing a chemical metaphor, as entities that are in themselves unsaturated, but that are saturated by their functional arguments, thus producing their functional values (see Frege's 1891 paper "Funktion und Begriff"). Therefore, instead of saying that

the functional value of the $\Phi$-concept for $\left\langle\alpha^{1}, \ldots, \alpha_{N}\right\rangle$ is the true, one can, following Frege, just as well say:

the saturation of the $\Phi$-concept by $\left\langle\alpha^{1}, \ldots, \alpha_{N}\right\rangle$ is the true.

This is still somewhat odd, the main reason for this impression being Frege's assumption of a truth-object, the true, corresponding to which he has an even odder falsity-object, the false. But notice the flexibility and ease Frege's predicationtheory displays in the treatment of relational predications. What is the ontological basis for the fact that the statement "George loves Kate" is true whereas "Kate loves George" is not true? Why, the saturation of the concept of love by the ordered pair that has George first and Kate second is the true, whereas the saturation of that same concept by the inversely ordered pair is the false.

There is nothing wrong with this - except, of course, that it does not make contact with what it actually is that we base our judgements on when we assert that George loves Kate, and that Kate does not love George. Frege's predicationtheory is a mere logical rationalisation of predication, not an account of predication that tries to honour the actual ontological foundation of our actual human practice of making simple predicative statements intended to be true - something which Aristotle's predication-theory, and, indeed, Plato's, did try to do, though not with entire success. As far as a mere logical rationalisation of predication goes, Frege's theory is true and adequate, just as true and adequate as its nearest equivalent not employing the notion of function is, which became a standardly used technical tool in $20^{\text {th }}$-century model-theoretic logical semantics:

The set-theoretical theory of predication:

" $\Phi\left(\alpha^{1}, \ldots, \alpha_{N}\right)$ " is true - this amounts, ontologically, to the following: $\left\langle\alpha^{1}, \ldots, \alpha_{N}\right\rangle$ is an element of the $\Phi$-set. ${ }^{14}$

${ }^{14}$ Frege's concepts (Begriffe) are extensional concepts (that is: they are identical if, and only if, they have the same extension); they are, therefore, one-to-one correlates of sets. Extensionality is not the only feature of Fregean concepts that fits ill with the normal concept of a concept: another is lack of mind-affinity (which is in part a consequence of their extensionality). Thus: Frege's use of the word "concept" ("Begriff") - for the items that are really intended by him still bears witness to the (above-described) emphasis on the conceptualness of universals, after the Middle Ages, but it does so only on the linguistic surface. 
But one certainly does not - not explicitly, and not implicitly - apply the set-theoretical theory of predication, or Frege's theory, when determining, for example, the truth of the statement "George loves Kate", nor would it be a good idea to apply these theories in the effort to explicate the ontological basis for the truth of "George loves Kate". The same can be said of an account that - restricted to non-relational predications - was in use as a purely logical tool throughout the entire Aristotelian tradition, which I therefore call

The minimal Aristotelian theory of predication:

" $\Phi\left(\alpha^{1}, \ldots, \alpha_{N}\right)$ " is true - this amounts, "ontologically", to the following: the (monadic or relational) $\Phi$-universal is said (truthfully) of $\left\langle\alpha^{1}, \ldots, \alpha_{N}\right\rangle$.

The three last-mentioned theories (beginning with Frege's), though true, have no belief-foundational and no truth-explanatory value. Though they do introduce onto-theoretical entities in order to account for predication - concepts, the truthobject, sets, universals - they, in essence, just reformulate the normal expression of predication in technical logico-ontological terms; though they have some ontological content, they, in essence, just logically rationalise predication..$^{15}$ They do so in keeping with the truth (though those who do not believe in universals or concepts or sets would deny this). But truth is not enough - as can easily be seen by a glance at what may be dubbed

The "redundancy theory" of predication:

" $\Phi\left(\alpha^{1}, \ldots, \alpha_{N}\right)$ " is true - this amounts, "ontologically", to this: $\Phi\left(\alpha^{1}, \ldots, \alpha_{N}\right)$.

Or by a glance at the so-called (historically not unimportant and, like the immediately preceding theory, nominalism-compatible)

"Identity theory" of predication:

" $\Phi(\alpha)$ " is true - this amounts, "ontologically", to this: " $\Phi$ " refers (as general term) to the same object that " $\alpha$ " refers to (as singular term).

These theories are obviously true (true for simple predicative statements as specified at the beginning of this essay, the "identity theory" being additionally restricted in its range to the non-relational ones among those statements); but just as obviously they are not helpful at all for belief-foundation or truth-explanation.

But here, finally, follows a theory of predication which, like Frege's, falls under the functional paradigm of predication. It is recognizably a modification of Frege's theory and preserves the great advantage of that theory: the capturing of

${ }^{15}$ If one leaves out Leibniz's assumption of the rigidity of the designator "the concept of $\alpha$ " (for example, "the concept of Caesar"; see footnote 13), then Leibniz's predication-theory turns out to be adequate also with respect to our normal modal expectations. But what it then offers is merely a true logical rationalisation of non-relational predication; it has no belief-foundational or truth-explanatory value. 
relational predications; but it is, in contrast to Frege's predication-theory, helpful for belief-foundation and truth-explanation. It is the theory I myself favour,

The fact-referring functional predication-theory:

" $\Phi\left(\alpha^{1}, \ldots, \alpha_{\mathrm{N}}\right)$ " is true - this amounts, ontologically, to the following: the completion of the $\Phi$-universal by $\left\langle\alpha^{1}, \ldots, \alpha_{N}\right\rangle$ is a fact, that is: an obtaining state of affairs.

Universals that need at least in some cases two entities for completion are called "relations", universals that always need only one entity for completion are called "properties". Thus, we have:

"Kate is a woman" is true - this amounts, ontologically, to the following: the completion of the woman-property (i.e., the property of being a woman) by Kate is a fact, or in other words: Kate has the property of being a woman.

"George loves Kate" is true - this amounts, ontologically, to the following: the completion of the love-relation (i.e., the relation of love) by $\langle$ George, Kate $\rangle$ is a fact, or in other words: George stands in the relation of love to Kate.

Facts - the states of affairs that obtain, or are actualised - are sometimes, in their factuality, a product purely of social conventions; but normally they are not. In any case, facts that are merely made up of universals and particulars - in a manner that I have here merely hinted at, using the metaphor of completion ${ }^{16}$ are the primary objects of human objective cognition, not particulars as such and not universals as such. To particulars and universals we come in cognition only via states of affairs that involve them, and foremost via facts that involve them. Because facts that are merely made up of universals and particulars are the primary objects of human objective cognition, the fact-referring functional predication-theory is helpful for founding belief in the truth, and for ontologically explaining the truth, of simple predicative statements. We apply this theory implicitly when we judge that a simple predicative statement is true, and we do well to apply this theory explicitly when we seek to explain, from the ontological point of view, why - that is, on what ontological basis - a simple predicative statement is true.

${ }^{16}$ The full theory is presented non-metaphorically in UWE MEIXNER, The Theory of Ontic Modalities (Heusenstamm bei Frankfurt a. M.: Ontos, 2006). 


\section{BIBLIOGRAPHY}

ALLEN, R. E. "Substance and Predication in Aristotle's Categories". In Exegesis and Argument. Studies in Greek Philosophy Presented to Gregory Vlastos, edited by. E. N. Lee et al., 362-373. Assen, Netherlands: van Gorcum, 1973.

ARISTOTLE. Kategorien. Hermeneutik. Vol. 2 of Organon. Edited by H.-G. Zekl. Darmstadt: Wissenschaftliche Buchgesellschaft, 1998.

— Erste Analytik. Zweite Analytik. Vol. 3-4 of Organon. Edited by H.-G. Zekl. Darmstadt: Wissenschaftliche Buchgesellschaft, 1998).

— Aristoteles' Metaphysik. Bücher I(A) - VI(E). Edited by H. Seidl. Hamburg: Meiner, 1989.

— Aristoteles' Metaphysik. Bücher VII(Z) - XIV(N). Edited by H. Seidl. Hamburg: Meiner, 1991.

BUTLER, JUDITH. Gender Trouble. Feminism and the Subversion of Identity. New York: Routledge, 1990.

FREGE, GOTTLOB. “Funktion und Begriff”. In Funktion, Begriff, Bedeutung, edited by G. Patzig, 17-39. Göttingen: Vandenhoeck \& Ruprecht, 1975.

HUSSERL, EDMUND. Phänomenologische Psychologie. Edited by D. Lohmar. Hamburg: Meiner, 2003.

KUTSCHERA, FRANZ VON. "Parts of Forms. An Essay concerning Plato's Parmenides". Logical Analysis and History of Philosophy 1 (1998): 57-74.

Leibniz, GotTfRied Wilhelm. "Discours de Métaphysique". In GotTfRIed WiLhelm LEIBNIZ, Opuscules Métaphysiques / Kleine Schriften zur Metaphysik, edited by H. H. Holz, 49-165. Darmstadt: Wissenschaftliche Buchgesellschaft, 1985.

MEIXNER, UWE. "Negative Theology, Coincidentia Oppositorum, and Boolean Algebra". Logical Analysis and History of Philosophy 1 (1998): 75-89.

— The Theory of Ontic Modalities. Heusenstamm bei Frankfurt a. M.: Ontos, 2006.

Plato. Phaidros. Parmenides. Epistolai. Vol. 5 of Werke in 8 Bänden. Edited by G. Eigler. Wissenschaftliche Buchgesellschaft: Darmstadt, 1990.

THomas Aquinas. In Aristotelis Libros Peri Hermeneias et Posteriorum Analyticorum Expositio. Cum textu ex recensione Leonina. Augusta Taurinorum: Marietti, 1964.

WitTGEnSTEIN, LUdWIG. Philosophical Investigations. New York: Macmillan, 1953. 